\title{
Organizational Performance in the Public Sector: An Analysis of the Gespública Program
}

\author{
Pedro Carlos Resende Junior
}

\begin{abstract}
This article seeks to analyze the performance of 32 Brazilian public organizations, assessed in the Gespública Program. In Gespública (2008), the performance of an organization is borne out in results that reflect the meeting of needs of concerned parties vis-à-vis the organization: service users, employees, providers, society and government. With respect to results, the article includes a performance comparison of organizations, using the Gespública criteria, in addition to an analysis of these criteria in relation to the "state of the domain", generated through a review of relevant literature. Theoretical and methodological conclusions and recommendations are proposed, as well as suggestions for research development.
\end{abstract}

Index Terms-Performance, management model, public sector, Gespública.

\section{INTRODUCTION}

In this article, the construct of performance is approached from an organizational perspective, focusing not on individual or team performance, but rather, on the expression resulting from the organization's assets, as manifested in its results. In Gespública (2008), [1] an organization's performance is made clear via results that reflect the meeting of needs of concerned parties vis-à-vis the organization: service users, employees, providers, society and government. Le Boterf (1999) [2] treats organizational performance as collective abilities that emerge from cooperation, exchanges and articulations developed by components of the organization.

Kaplan and Norton (1997) [3] argue that the performance of an organization should be balanced using a set of measures that translate performance dimensions in accordance with the organization's systemic vision. Performance measurement practices vary between different organizations and levels of one same organization. The aforementioned authors advocate the organizational performance measurement embodied in the model termed Balanced Scorecard (BSC). This model approaches performance from four perspectives: finance; clients; processes; and learning and growth. According to the authors, this structure allows for a systemic vision and favors the balancing of results regarding strategic areas of the organization. The basis of the model lies in an integrated system of indicators relating to results and processes that concern various levels of the organization.

Organizational performance assessment methods and

Manuscript received October 19, 2013; revised December 20, 2013.

Pedro Carlos Resende Junior is with the University of Brasília, Brasília, DF, Brazil (e-mail: pcrj73@gmail.com). methodologies in the public sector represent part of an impetus to bring about the institutionalization of New Public Administration. From the government's standpoint, the processes, products and services delivered to citizens and society as a whole, can also be judged according to these conditions, forcing public management to reinvent itself, in the quest for better practices, more efficient processes and excellent results [4], [5]. It is understood that, in order to minimize the effects of the complexity of public management, the application of management models and performance assessment generally aids public sector organizations in the constant search for innovation.

\section{The Excellence Model IN Public Management (GESPÚBLICA)}

The excellence model in public management (Gespública), the fruit of the fusion between the previous programs, Quality Program in Public Service (QPPS) and National Debureaucratization Program (NDP), aims to enhance the country's competitiveness, focusing on excellence in the provision of public services to citizens. In accordance with Gespública (2008), the overall performance of public organizations, which strive for efficient management, is generally gauged by considering commitment to management practices and attainment of objectives and targets, which can be measured by indicators devised according to the organizations' strategic orientation.

Gespública represents the main reference to be followed by Brazilian public organizations seeking to enhance management. Gespública outlines 13 management principles: systemic thinking; organizational learning; innovation culture; leadership and constancy of commitments; orientation by processes and information; vision for the future; generation of value; commitment to people; focus on citizens and society; development of partnerships; social responsibility; social control; and participatory management.

The model uses eight management assessment criteria for public organizations: leadership; strategies and plans; citizens; information and knowledge; people; processes; and results. These principles and criteria are measured and analyzed using standards set out in the Instrument for the Assessment of Management and Management Practices. Every excellence criterion contains descriptions of recognized management practices, such as the state of the domain of public administration.

These criteria are distributed across four blocks. The first block (leadership, strategies and plans, citizens and society) is termed planning. The second block (people and processes) represents the execution of planning. The third block (results) symbolizes control. The fourth block (information 
and knowledge) represents the organization's intelligence to correct or improve management practices and consequently, its performance.

In addition to addressing the conceptual premises of the model per se, the public organization needs to consider certain issues regarding its entourage in implementing management practices, for instance, the institutional conditions for their development and diffusion, the cultural conditions that underlie the characteristics of supply and demand by innovations, and the role of managers in creating and implementing new management practices.

\section{METHOD}

This study is descriptive in nature, insofar as it seeks to describe the performances of the organizations that made the final of the 2008 cycle of the Gespública Program. As regards approach, the study can be regarded as quantitative, analyzing secondary data on the performance of organizations, made available by the Ministry of Planning.

In order to revise the construct of organizational performance in public service organizations, the following sources were consulted: ENAP (National School of Public Administration), CAPES, PROQUEST, SAGE Online Journals, Emerald and Oxford Journals. The latter cover the most significant periodicals in the indexed literature, using the keywords "organizational performance" and "public services".

This study comprises 32 Brazilian public organizations that made the final of the 2008 cycle of the Gespública Program. All of these organizations are from the services sector. These organizations operate in the most diverse fields of activity, such as: finance; energy; sanitation; health; the armed forces; logistics; city government; research and civil defense.

\section{AnAlyses of PERFoRMAnCE Data RElating to BRAZILIAN ORGANIZATIONS}

This section outlines the performance results of Brazilian organizations that made the final of the 2008 cycle of Gespública, based on secondary data gathered during the documental analysis stage. For the purposes of these results, the field of activity and level of administration were taken into account, for each of the eight criteria of the assessment model applied to the organizations: leadership; strategies and plans; citizens; society; information and knowledge; people; processes; and, results. Table I displays the organizations included in the sample and the respective fields of activity and management levels.

TABLE I: BEHAVIOR OF ORGANIZATIONS ACCORDING TO ACTIVITY FIELD AND MANAGEMENT LEVEL

\begin{tabular}{|c|c|c|c|}
\hline Org. & Field & Level & Organization \\
\hline 1 & Finance & Federal & Banco do Brasil S.A. - Comptroller Department \\
\hline 2 & Finance & Federal & Banco do Brasil S.A. - Credit Department \\
\hline 3 & Finance & State & Banco do Nordeste do Brasil S.A. \\
\hline 4 & Energy \& San. & State & CAGECE - Water and Sewerage Company of Ceará \\
\hline 5 & Firefighters & State & CBMERJ - Military Fire Dept. of the State of Rio de Janeiro \\
\hline 6 & Armed Forces & Federal & EB - 11th Light Anti-aircraft Artillery Battery \\
\hline 7 & Armed Forces & Federal & EB - 16th Mechanized Cavalry Regiment \\
\hline 8 & Armed Forces & Federal & EB - 1st Army Accounting and Finance Inspectorate \\
\hline 9 & Armed Forces & Federal & EB - 22nd Infantry Battalion \\
\hline 10 & Armed Forces & Federal & EB - 24th Hunters Battalion - Barão de Caxias Battalion \\
\hline 11 & Armed Forces & Federal & EB -35 th Infantry Battalion \\
\hline 12 & Armed Forces & Federal & EB - Police Battalion of the Brasilia Army \\
\hline 13 & Armed Forces & Federal & EB - Military College of Brasilia \\
\hline 14 & Armed Forces & Federal & EB - Military College of Fortaleza \\
\hline 15 & Armed Forces & Federal & EB - Army Admin. School and Military College of Salvador \\
\hline 16 & Armed Forces & Federal & EB - Army Chemical-Pharmaceutical Laboratory \\
\hline 17 & Postal Services & Federal & ECT - Regional Department for Brasilia Postal Services \\
\hline 18 & Energy \& San. & State & Boa Vista Energia \\
\hline 19 & Energy \& San. & Federal & Eletronorte - Regional Transmission Unit of Maranhão \\
\hline 20 & Energy \& San. & Federal & Eletronorte - Regional Transmission Unit of Mato Grosso \\
\hline 21 & Energy \& San. & Federal & Eletronorte - Opertns. Engin. \& Transmission Maint. Inspectorate \\
\hline 22 & Energy \& San. & Federal & Eletronorte - Reg. Product. and Commercialization Unit of Rondônia \\
\hline 23 & Energy \& San. & Federal & Eletronorte - Research \& Technological Development Inspectorate \\
\hline 24 & Energy \& San. & Federal & Eletronorte - Regional Transmission Unit of Tocantins \\
\hline 25 & Energy \& San. & State & EMAE - Center for Excellence in Maintenance \\
\hline 26 & Energy \& San. & State & EMAE - Henry Borden Factory \\
\hline 27 & Research & Federal & EMBRAPA - Tabuleiros Costeiros Research Center \\
\hline 28 & Hospital & State & HEMOPA - Hemotherapy and Hematology Center of Pará Found. \\
\hline 29 & Hospital & State & Albert Sabin Children's Hospital \\
\hline 30 & Armed Forces & Federal & MB - Housing Fund for Navy Personnel \\
\hline 31 & City Gov. & Municipal & Sub-city Hall of M'Boi Mirim - SP \\
\hline 32 & City Gov. & Municipal & Sub-city Hall of São Miguel - SP \\
\hline
\end{tabular}




\section{A. Leadership Criterion}

As Table II shows, the average and standard deviation of the organizations that made the final for this criterion were
$35.80 \%$ and $17.17 \%$, respectively. Despite the high variability in the observations, there were no outliers.

TABLE II: BEHAVIOR OF ORGANIZATIONS ACCORDING TO ACTIVITY FIELD AND MANAGEMENT LEVEL

\begin{tabular}{|c|c|c|c|c|c|c|c|}
\hline & $A$ & Mode & $M d n$ & $S^{2}$ & $S D$ & Min. & Max. \\
\hline Leadership & 35.80 & 17.30 & 32.70 & 294.87 & 17.17 & 10.00 & 75.50 \\
\hline Municipal & 32.75 & & 32.75 & 477.41 & 21.85 & 17.30 & 48.20 \\
\hline State & 31.13 & & 34.55 & 206.97 & 14.39 & 10.00 & 50.00 \\
\hline Federal & 37.77 & 30.00 & 32.70 & 330.27 & 18.17 & 10.00 & 75.50 \\
\hline Civil Defense & 10.00 & & 10.00 & & & 10.00 & 10.00 \\
\hline Energy and Sanitation & 47.27 & 60.00 & 41.80 & 317.18 & 17.81 & 24.50 & 75.50 \\
\hline Finance & 44.53 & 50.00 & 50.00 & 89.65 & 9.47 & 33.60 & 50.00 \\
\hline Armed Forces & 30.84 & 17.30 & 30.90 & 212.33 & 14.57 & 10.00 & 55.50 \\
\hline Hospital & 18.15 & & 18.15 & 41.41 & 6.43 & 13.60 & 22.70 \\
\hline Logistics & 30.00 & & 30.00 & & & 30.00 & 30.00 \\
\hline City Gov. & 32.75 & & 32.75 & 477.41 & 21.85 & 17.30 & 48.20 \\
\hline & $A$ & Mode & $M d n$ & $S^{2}$ & $S D$ & Min. & Max. \\
\hline Strategies \& Plans & 35.94 & 30.00 & 30.00 & 441.03 & 21.00 & 10.00 & 85.00 \\
\hline Municipal & 40.00 & & 40.00 & 1.800 .00 & 42.43 & 10.00 & 70.00 \\
\hline State & 35.00 & 50.00 & 35.00 & 142.86 & 11.95 & 20.00 & 50.00 \\
\hline Federal & 35.91 & 30.00 & 30.00 & 515.80 & 22.71 & 10.00 & 85.00 \\
\hline Civil Defense & 20.00 & & 20.00 & & & 20.00 & 20.00 \\
\hline Energy and Sanitation & 47.50 & 40.00 & 45.00 & 490.28 & 22.14 & 10.00 & 85.00 \\
\hline Finance & 43.33 & 50.00 & 50.00 & 133.33 & 11.55 & 30.00 & 50.00 \\
\hline Armed Forces & 29.58 & 30.00 & 30.00 & 356.63 & 18.88 & 10.00 & 70.00 \\
\hline Hospital & 25.00 & & 25.00 & 50.00 & 7.07 & 20.00 & 30.00 \\
\hline Research & 30.00 & & 30.00 & & & 30.00 & 30.00 \\
\hline
\end{tabular}

TABLE IV: BEHAVIOR OF ORGANIZATIONS ACCORDING TO ACTIVITY FIELD AND MANAGEMENT LEVEL

\begin{tabular}{|c|c|c|c|c|c|c|c|}
\hline & $A$ & Mode & $M d n$ & $S^{2}$ & $S D$ & Min. & Max. \\
\hline Citizens & 37.66 & 50.00 & 40.00 & 269.33 & 16.41 & 10.00 & 80.00 \\
\hline Municipal & 47.50 & & 47.50 & 2.112 .50 & 45.96 & 15.00 & 80.00 \\
\hline State & 41.25 & 50.00 & 50.00 & 233.93 & 15.29 & 10.00 & 55.00 \\
\hline Federal & 35.45 & 30.00 & 35.00 & 199.78 & 14.13 & 10.00 & 60.00 \\
\hline Civil Defense & 10.00 & & 10.00 & & & 10.00 & 10.00 \\
\hline Energy \& Sanitation & 45.50 & 50.00 & 50.00 & 146.94 & 12.12 & 20.00 & 60.00 \\
\hline Finance & 31.67 & 30.00 & 30.00 & 8.33 & 2.89 & 30.00 & 35.00 \\
\hline Armed Forces & 35.42 & 40.00 & 40.00 & 215.72 & 14.69 & 10.00 & 60.00 \\
\hline Hospital & 40.00 & & 40.00 & 200.00 & 14.14 & 30.00 & 50.00 \\
\hline Research & 15.00 & & 15.00 & & & 15.00 & 15.00 \\
\hline Logistics & 30.00 & & 30.00 & & & 30.00 & 30.00 \\
\hline City Gov. & 47.50 & & 47.50 & 2.112 .50 & 45.96 & 15.00 & 80.00 \\
\hline
\end{tabular}

It is also apparent that organizations operating at federal level presented higher indexes than those operating at state and municipal levels, with an average of $37.77 \%$. The outstanding organization as regards this criterion, with $75 \%$ of the 110 points, was Eletronorte - Operations Engineering and Transmission Maintenance Inspectorate.

\section{B. Strategies and Plans Criterion}

The sum of the strategies and plans items bears a maximum value of 60 points. The organizations that were finalists for this criterion, in accordance with Table II, obtained on average $35.94 \%$ of the maximum score. 
Organizations operating at federal level presented higher indexes than those operating at state or municipal levels, with an average of $47.50 \%$. By analyzing the data from Table III, it is possible to appreciate the homogeneity of the behavior of the data.

Again, Eletronorte-Operations Engineering and Transmission Maintenance Inspectorate, was the bestperforming organization from the sample, with $85 \%$ of the maximum score regarding this criterion.

\section{Citizens Criterion}

The citizens criterion bears a maximum value of 60 points. As Table IV shows, the average for the organizations that made the final was $37.66 \%$ and the standard deviation was $16.41 \%$.

Comparing the highest score values obtained by the organizations that made the final for each criterion, the citizens criterion appeared as the second best-placed, and the one for which the highest average was obtained $(37.66 \%)$. It is also apparent that the highest score, of $80 \%$, went to the Sub-city Hall of São Miguel, the municipal public administration organization.

\section{Society Criterion}

The sum of the items for the society criterion bears the maximum value of 60 points. By comparing the scores of the organizations that made the final, for this criterion as well as the others, it becomes clear that they obtained the lowest average and lowest standard deviation, of $28.24 \%$ and $14.46 \%$, respectively.

Despite the poor average, the indexes for administrations from the municipal sphere were higher than those from the federal and state spheres. Eletronorte - Operations Engineering and Transmission Maintenance Inspectorate, stood out in terms of performance for this criterion, with $56.70 \%$ of the possible 60 points.

The variability of the observations is not high and there are no outliers.

The society criterion, as well as allowing for the implementation of management processes related to the management of the responsibilities of organizations before society and communities directly affected by their processes, services and products, stimulates citizenship, the participation of society in scrutinizing the organization's activities, transparency, ethical behavior and sustainable development.

TABLE V: BEHAVIOR OF ORGANIZATIONS ACCORDING TO ACTIVITY FIELD AND MANAGEMENT LEVEL

\begin{tabular}{lccccccc}
\multicolumn{7}{c}{ FIELD AND MANAGEMENT LEVEL } \\
\hline & $\boldsymbol{A}$ & Mode & $\boldsymbol{M} \boldsymbol{d n}$ & $\boldsymbol{S}^{\mathbf{2}}$ & $\boldsymbol{S D}$ & Min. & Max. \\
\hline Society & 28.24 & 16.70 & 26.70 & 209.23 & 14.46 & 6.70 & 56.70 \\
Municipal & 38.35 & & 38.35 & 139.45 & 11.81 & 30.00 & 46.70 \\
State & 26.26 & 10.00 & 21.70 & 239.24 & 15.47 & 10.00 & 50.00 \\
Federal & 28.04 & 16.70 & 25.00 & 211.21 & 14.53 & 6.70 & 56.70 \\
Civil & 10.00 & & 10.00 & & & 10.00 & 10.00 \\
Defense & & & & & & & \\
Energy \& & 38.01 & 43.30 & 41.65 & 192.74 & 13.88 & 16.70 & 56.70 \\
Sanitation & & & & & & & \\
Finance & 34.47 & & 36.70 & 280.96 & 16.76 & 16.70 & 50.00 \\
Armed & 21.96 & 30.00 & 20.00 & 128.22 & 11.32 & 6.70 & 46.70 \\
Forces & & & & & & & \\
Hospital & 13.35 & & 13.35 & 22.45 & 4.74 & 10.00 & 16.70 \\
Research & 20.00 & & 20.00 & & & 20.00 & 20.00 \\
Logistics & 23.30 & & 23.30 & & & 23.30 & 23.30 \\
City Gov. & 38.35 & & 38.35 & 139.45 & 11.81 & 30.00 & 46.70 \\
\hline
\end{tabular}

\section{E. Information and Knowledge Criterion}

The information and knowledge criterion bears a maximum value of 60 points, As Table VI shows, the finalists for this criterion obtained an average of $34.37 \%$ and had a mode of $43.30 \%$. Unlike the previous criterion, the municipal level revealed significantly lower indexes than those of the other two levels.

The outstanding organization regarding this criterion was the federal organization Eletronorte - Regional Transmission Unit of Mato Grosso, from the energy and sanitation sector, with an index of $73.3 \%$. By comparing the highest scores obtained by the finalists for each criterion, among the eight criteria, the criterion information and knowledge appears as the fifth best-placed.

TABLE VI: BEHAVIOR OF ORGANIZATIONS ACCORDING TO ACTIVITY FIELD AND MANAGEMENT LEVEL

\begin{tabular}{|c|c|c|c|c|c|c|c|}
\hline & $A$ & Mode & $M d n$ & $S^{2}$ & $S D$ & Min. & Max. \\
\hline & 34.37 & 43.30 & 30.00 & 310.92 & 17.63 & 10.00 & 73.30 \\
\hline \multicolumn{8}{|c|}{ Information \& Knowledge } \\
\hline Municipal & 13.35 & & 13.35 & 22.45 & 4.74 & 10.00 & 16.70 \\
\hline State & 30.00 & 43.30 & 28.35 & 180.76 & 13.44 & 10.00 & 46.70 \\
\hline Federal & 37.87 & 63.30 & 33.35 & 335.48 & 18.32 & 13.30 & 73.30 \\
\hline Civil Defense & 10.00 & & 10.00 & & & 10.00 & 10.00 \\
\hline Energy \& Sanitation & 50.32 & 63.30 & 55.00 & 333.54 & 18.26 & 16.70 & 73.30 \\
\hline Finance & 38.90 & & 36.70 & 103.63 & 10.18 & 30.00 & 50.00 \\
\hline Armed Forces & 29.71 & 43.30 & 28.35 & 123.91 & 11.13 & 13.30 & 43.30 \\
\hline Hospital & 20.00 & & 20.00 & 21.78 & 4.67 & 16.70 & 23.30 \\
\hline Research & 20.00 & & 20.00 & & & 20.00 & 20.00 \\
\hline Logistics & 26.70 & & 26.70 & & & 26.70 & 26.70 \\
\hline City Gov. & 13.35 & & 13.35 & 22.45 & 4.74 & 10.00 & 16.70 \\
\hline
\end{tabular}




\section{F. People Criterion}

The people criterion bears a maximum value of 90 points. Table VII shows that the average and standard deviation of the finalists for this criterion were $36.04 \%$ and $18.27 \%$, respectively.

TABLE VII: BEHAVIOR OF ORGANIZATIONS ACCORDING TO ACTIVITY

\begin{tabular}{lccccccc}
\multicolumn{7}{c}{ FIELD AND MANAGEMENT LEVEL } \\
\hline & $\boldsymbol{A}$ & Mode & $\boldsymbol{M} \boldsymbol{d} \boldsymbol{n}$ & $\boldsymbol{S}^{\mathbf{2}}$ & $\boldsymbol{S D}$ & Min. & Max. \\
\hline People & 36.04 & 16.70 & 33.35 & 333.70 & 18.27 & 10.00 & 66.70 \\
Municipal & 26.70 & & 26.70 & 200.00 & 14.14 & 16.70 & 36.70 \\
State & 30.81 & 43.30 & 35.00 & 278.45 & 16.69 & 10.00 & 53.30 \\
Federal & 38.80 & 56.70 & 33.35 & 363.59 & 19.07 & 10.00 & 66.70 \\
Civil & 10.00 & & 10.00 & & & 10.00 & 10.00 \\
Defense & & & & & & & \\
Energy \& & 48.33 & 56.70 & 55.00 & 316.70 & 17.80 & 10.00 & 66.70 \\
Sanitation & & & & & & & \\
Finance & 40.00 & & 43.30 & 143.89 & 12.00 & 26.70 & 50.00 \\
Armed & & & & & & & \\
Forces & 32.78 & 23.30 & 26.65 & 260.56 & 16.14 & 16.70 & 60.00 \\
Hospital & 13.30 & 13.30 & 13.30 & 0.00 & 0.00 & 13.30 & 13.30 \\
Research & 16.70 & & 16.70 & & & 16.70 & 16.70 \\
Logistics & 50.00 & & 50.00 & & & 50.00 & 50.00 \\
City Gov. & 26.70 & & 26.70 & 200.00 & 14.14 & 16.70 & 36.70 \\
\hline
\end{tabular}

It is also clear that federal-level organizations had higher indexes than those of state and municipal levels, with an average of $38.8 \%$. The two segments that stood out most were energy and sanitation, with $48.33 \%$, and the armed forces, with $32.78 \%$, as respective averages. The organization Eletronorte-Research \& Technological Development Inspectorate, excelled the most, with $66.70 \%$ of the 90 possible points for this criterion.

\section{G. Processes Criterion}

TABLE VIII: BEHAVIOR OF ORGANIZATIONS ACCORDING TO ACTIVITY FIELD AND MANAGEMENT LEVEL

\begin{tabular}{lccccccc}
\hline & $\boldsymbol{A}$ & $\boldsymbol{M o d e}$ & $\boldsymbol{M d n}$ & $\boldsymbol{S}^{\mathbf{2}}$ & $\boldsymbol{S D}$ & Min. & Max. \\
\hline Processes & 34.74 & 30.00 & 30.00 & 265.31 & 16.29 & 10.00 & 79.10 \\
Municipal & 32.75 & & 32.75 & 595.13 & 24.40 & 15.50 & 50.00 \\
State & 35.23 & 48.20 & 40.90 & 205.24 & 14.33 & 10.00 & 48.20 \\
Federal & 34.75 & 30.00 & 30.00 & 294.43 & 17.16 & 15.50 & 79.10 \\
Civil & 10.00 & & 10.00 & & & 10.00 & 10.00 \\
Defense & & & & & & & \\
Energy \& & 52.09 & 48.20 & 49.10 & 191.18 & 13.83 & 33.60 & 79.10 \\
Sanitation & & & 30.00 & 210.25 & 14.50 & 15.50 & 44.50 \\
Finance & 30.00 & & & & & & \\
Armed & 27.12 & 24.50 & 25.00 & 58.05 & 7.62 & 17.30 & 39.10 \\
Forces & & & 24.55 & 59.41 & 7.71 & 19.10 & 30.00 \\
Hospital & 24.55 & & 22.70 & & & 22.70 & 22.70 \\
Research & 22.70 & & 28.20 & & & 28.20 & 28.20 \\
Logistics & 28.20 & & 32.75 & 595.13 & 24.40 & 15.50 & 50.00 \\
City Gov. & 32.75 & & & & & & \\
\hline
\end{tabular}

The processes criterion bears a maximum value of 110 points. This was the third-top criterion in terms of performance. The finalists for this criterion obtained, on average, $34.74 \%$ of the total.

The highest score $(79.1 \%)$ was gained by the organization Eletronorte - Regional Transmission Unit of Mato Grosso, from the federal sphere and energy and sanitation sector. There was little variability between the averages of the municipal, state and federal levels, although state-level organizations had higher indexes than the other two, with an average of $35.23 \%$.

\section{H. Results Criterion}

The results criterion bears the maximum value of 450 points. Drawing on Table VIII, the average and standard deviation of organizations that made the final for this criterion were $29.03 \%$ and $15.68 \%$, respectively. Although the variability of the observations is not low, there are no outliers. In addition, it is apparent that $59.4 \%$ of the organizations are situated at a distance from the average that is inferior to a standard deviation.

TABLE IX: BEHAVIOR OF ORGANIZATIONS ACCORDING TO ACTIVITY

\begin{tabular}{lccccccc}
\multicolumn{7}{c}{ FIELD AND MANAGEMENT LEVEL } \\
\hline & $\boldsymbol{A}$ & $\boldsymbol{M o d e}$ & $\boldsymbol{M} \boldsymbol{d} \boldsymbol{n}$ & $\boldsymbol{S}^{\mathbf{2}}$ & $\boldsymbol{S} \boldsymbol{D}$ & Min. & Max. \\
\hline Results & 29.03 & 47.30 & 31.75 & 245.94 & 15.68 & 2.20 & 53.10 \\
Municipal & 3.55 & & 3.55 & 3.65 & 1.91 & 2.20 & 4.90 \\
State & 21.34 & & 19.30 & 298.16 & 17.27 & 2.70 & 47.30 \\
Federal & 34.15 & 21.80 & 34.80 & 151.70 & 12.32 & 7.80 & 53.10 \\
Civil & 47.30 & & 47.30 & & & 47.30 & 47.30 \\
Defense & & & & & & & \\
Energy \& & 36.45 & 44.90 & 41.45 & 248.90 & 15.78 & 2.70 & 53.10 \\
Sanitation & & & 19.60 & 55.76 & 7.47 & 7.60 & 21.30 \\
Finance & 16.17 & & & & & & \\
Armed & 32.00 & & 33.10 & 147.04 & 12.13 & 7.80 & 50.90 \\
Forces & 10.10 & & 10.10 & 54.08 & 7.35 & 4.90 & 15.30 \\
Hospital & 10.80 & & 21.80 & & & 21.80 & 21.80 \\
Research & 21.80 \\
Logistics & 35.60 & & 35.60 & & & 35.60 & 35.60 \\
City & 3.55 & 3.55 & 3.65 & 1.91 & 2.20 & 4.90 \\
Gov. & & & & & & & \\
\hline
\end{tabular}

Further, it can be noted that federal-level organizations presented higher indexes than those operating at state and municipal levels, with an average of $34.15 \%$. The two segments that stood out most were the organizations from energy and sanitation, with $36.45 \%$, and the armed forces, with $32 \%$ on average. The organization Eletronorte Regional Transmission Unit of Tocantins obtained the highest score in the sample, with $53.10 \%$ of the points for this criterion.

Comparing the average maximum and minimal scores, the society criterion reveals the worst performance on the part of public organizations, and is regarded as a deficiency in the management of these organizations.

\section{RESULTS AND CONCLUSION}

This study noted the complexity involved in analyzing performance in the public realm, particularly when considering only the results, ignoring the support processes, final processes and culture of the organization.

Most of the Gespública criteria feature in the literature on performance in public organizations, which demonstrates the theoretical consistency of this model. For the purposes of future studies, it is recommended that qualitative analyses be carried out, allowing for the gathering of data directly from senior management, and from mid-level management for organizations with outstanding performances according to the model. This would also favor the development, validation and application of sectoral organizational performance assessment scales that take into account the contingencies of the public sector. 


\section{REFERENCES}

[1] Gespública, "Programa nacional de gestão pública e desburocratização - ministério do planejamento," Critérios de Avaliação 2008, Brasília: Gespública, 2008.

[2] G. L. Boterf, Competénce et Navigation Professionelle, Paris: Éditions d'Organization, 1999.

[3] S. R. Kaplan and D. P. Norton, A Estratégia Em Ação: Balanced Scorecard, Rio de Janeiro: Campus, 1997.

[4] W. H. Oakland, "Theory of public goods," Em A. J. Auerbach \& M. Feldstein (Orgs.), Handbook of Public Economics, Elsevier, pp. 485535, 1987.

[5] L. Bardin, Análise de Conteúdo, Lisboa: Edições 70, 2002.

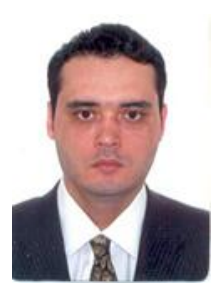

Pedro Carlos Resende Junior was born in Brazil, Espírito Santo, Colatina, on December 7, 1973. He received doctor in Business Administration, University of Brasília. Master in Business Administration, University of Brasília. Postgraduate in Information Engineering, Federal University of Espírito Santo. Postgraduate in Quality and Productivity, Federal University of Espírito Santo. Postgraduate in Marketing, Federal University of Espírito Santo. He has worked for 15 years in public organizations, and come from the private sector. He has worked in corporate projects, having held technical and management functions in the areas of Innovation, Research and Marketing, Quality, Strategic Planning and Corporate Education. He acts as instructor and examiner in several National Awards for Quality. Dr. Resende Junior, researcher and professor in professional master in Administration at University of Brasília 